\title{
Adding Value to Logistic Delivery through Package Marketing
}

\author{
Chiung-Lin Liu \\ Department of Shipping and Transportation Management, National Taiwan Ocean University, 2 Beining Road, \\ Keelung City, Taiwan \\ Email: realsky@ntou.edu.tw (Corresponding Author)
}

Chun-Wei Chiang

Kerry Logistics, 14F, 50 Xinsheng South Road Section 1, Taipei City, Taiwan

Email: joe.chiang@kerrytj.com

\begin{abstract}
The objective of this study was to evaluate whether package marketing can add value to logistic delivery and to discuss how package marketing influences customers' purchase intention. A survey of 184 consumers in Taiwan was carried out using structural equation modelling. A direct positive relationship between attitude toward package marketing and attitude toward advertising was identified. Specifically, it was confirmed that attitude toward advertising plays a mediating role between attitude toward package marketing and purchase intention. Overall, when companies attach marketing advertisements in a package in the future, the key is to include advertisement contents that could result in consumers' positive attitude and influence their purchase intention.
\end{abstract}

Keywords: value-added, logistic delivery, package marketing, purchase intention, consumer

\section{INTRODUCTION}

Service innovation and value-added services have already become new sources of profits in the supply chain (Gnanendran and Iacocca, 2015; Lin and Chen, 2015; von Massow and Canbolat, 2014). One of the examples in recent years is that with the increasing popularity of online shopping, companies have begun to adopt deliverymen as a novel communication medium and require them to perform personal selling (Bode et al., 2011) in response to the increased need for delivery services, developing another way of making corporate profits. Many factors should be considered in order to maximize the effects of communication media. For example, a deliveryman who performs personal selling not only has to maintain a good quality personal contact with the customers, but also to control the frequency of contact and focus on specific clients (Bode et al., 2011). Although previous studies have indicated that using deliverymen as the communication medium for personal selling could benefit companies, there is still insufficient evidence about the effects of applying tools of marketing communications to other communication media related to logistics, such as package delivery. According to past transaction records with customers, companies could put commercial pamphlets and coupons of all kinds into packages to perform differentiated marketing, and logistics companies could increase the added-value of logistic delivery.

One of the major factors that could contribute to sustainable business operation is customers' attitude toward advertising and purchase intention (Ham and Lee, 2015; Huh et al., 2015; Jacobs et al., 2011; Kotler et al., 2013; Sabour et al., 2016). There are numerous factors influencing the attitude toward advertising, such as choosing the appropriate type of endorsers (e.g., Stafford et al., 2002), selecting entertaining contents (e.g., Zhang and Zinkhan, 2006), and communicating familiar feelings (e.g., Moorman et al., 2002). Similarly, a great amount of studies have investigated possible factors influencing purchase intention, including service quality (e.g., Keaveney and Parthasarathy, 2001) and customer loyalty (e.g., Oliver et al., 1997). However, there has been relatively little attention given to empirical studies discussing whether attitude toward package marketing would influence attitude toward advertising and purchase intention. "Attitude toward package marketing" in this context indicates consumers' feelings of favourability/unfavourability toward the marketing communication tools that come with the packages, such as advertising, sales promotion, and personal selling.

Existing research on the relationships between attitude toward package marketing, attitude toward advertising, and purchase intention has made only a limited contribution to the possible correlations between these factors. Therefore, this research set out to address these gaps by empirically exploring the relationships between attitude toward package marketing, attitude toward advertising, and purchase intention from a consumer's perspective.

Key questions posed by this research include the following:

- What are the effects of attitude toward package

marketing on attitude toward advertising?

- What are the effects of attitude toward package marketing on purchase intention? 
The aim of this article is to present the results of an investigative study evaluating consumer attitudes, fill a series of gaps in the literature, and extend the prevailing theory by exploring the relationship between attitude toward package marketing, attitude toward advertising, and purchase intention. The package marketing communication tools discussed in this study were limited to sales promotion, among the other marketing communication tools. Moreover, the sample population of this study were Taiwanese consumers because of the following reasons: First, up to $60 \%$ of Taiwanese people have attempted online purchase (Institute for Information Industry (Taiwan), 2013), thereby forming a beneficial condition for companies to conduct package marketing. Second, due to the similarity of cultures between Taiwan and China, the research results about Taiwan could probably serve as a reference for companies to employ package marketing strategies in China.

\section{LITERATURE REVIEW AND RESEARCH HYPHOTHESES}

\subsection{Attitude Toward Package Marketing}

Attitude toward package marketing in this study concerns consumers' feelings of favourability/unfavourability toward the marketing communication tools attached in the packages, such as advertising, sales promotion, and personal selling. Marketing communications are methods attempted by companies to directly or indirectly inform, convince, and remind consumers of business products and brands (Kotler et al., 2013). Effective marketing communications could not only benefit brand equity by establishing brand recognition and brand images, but also increase sales and improve the benefits of stockholders (Luo and Donthu, 2006; Ots and Nyilasy, 2015; Seric et al., 2015).

According to the model of consumer behaviour (Kotler et al., 2013), external stimuli (e.g., product information) would affect the consciousness of consumers and influence their purchase decisions. If consumers hold positive attitudes toward package marketing (e.g., willing to take a look at the pamphlets within packages), chances of their encounter with external stimuli are increased, and their consciousness and purchase intention may be subsequently influenced. Such discussions would lead to the following hypotheses:

H1: Attitude toward package marketing is positively correlated with attitude toward advertising.

H2: Attitude toward package marketing is positively correlated with purchase intention.

\subsection{Attitude Toward Advertising}

Attitude is one of the core elements that influence behavioural intention (Ajzen and Fishbein, 1980; Choi et al., 2013; Kim et al., 2013; Lin et al., 2016; Van et al., 2014), and it indicates people's emotional feelings about something (Kotler et al., 2013). Attitude toward advertising concerns "consumers' feelings of favourability/unfavourability toward the advertising itself" (MacKenzie et al., 1986). A large amount of studies have verified the positive influences of attitude toward advertising on purchase intention (e.g., MacKenzie et al., 1986; Shimp, 1981). For example, the Independent Influences Hypothesis proposed by MacKenzie et al. (1986) indicates that purchase intention would be directly influenced by attitude toward advertising. The research by Ajzen and Fishbein (1980) also notes that purchase intention will be affected through demand function, thereby influencing actual purchase behaviour, when customers possess positive attitude toward advertising and have demand for related products. As Shimp (2010) pointed out in the Advertising Response Model that they developed, customers' attitude toward advertising would influence their buying interest. Therefore, we proposed the following additional hypothesis:

H3: Attitude toward advertising is positively correlated with purchase intention.

\subsection{Purchase Intention}

Purchase intention indicates the possibilities that consumers will buy a certain product or service (Dedeke, 2016; Hsu et al., 2015; Lu et al., 2016; Schiffman et al., 2010). This factor is mostly determined by consumers' subjective perception of what they give and take (Zeithaml, 1988); higher purchase intention suggests a higher possibility to purchase the product (Schiffman et al., 2010). There have been many indicators of purchase intention proposed by various studies. For example, Shamdasani et al. (2001) adopted the possibility of resulting in purchase behaviour and recommended level as the references for purchase intention. Several literature proposed their evaluation indicators based on this concept, such as "I am very likely to purchase the products of this brand," "I will choose this brand in the future if I have a demand for this product," "I will definitely try the products of this brand" used to measure purchase intention by Putrevu and Lord (1994). Nevertheless, Zeithaml (1988) used perceived values to measure purchase intention, such as "likely to purchase," "want to purchase," and "considering to purchase." Boyd and Mason (1999), however, adopted the timing of purchase as the references of evaluating purchase intention. For example, immediate purchase represents high purchase intention, purchase after one year represents moderate purchase intention, and purchase after several years represents low purchase intention. In other words, the longer the period of purchase, the lower the intention to buy. With reference to the foregoing literature review, a conceptual model is proposed in Figure 1.

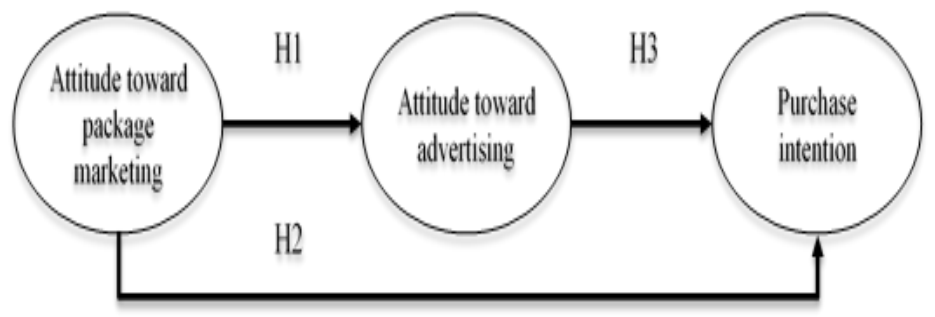

Figure 1: The Proposed Model of the Present Study 


\section{METHODS}

\subsection{Sampling}

This study retrieved samples from PTT, a bulletin board system in Taiwan. PTT is a comprehensive system that possesses the highest number of average daily users in Taiwan. During its traffic peak of the day, there could be more than 150 thousand concurrent users, who range between $15-45$ years of age. This is exactly the range of ages of primary online consumers in Taiwan (70\% of the online shoppers in Taiwan range between 15 - 45 years of age) (Institute for Information Industry (Taiwan), 2013). Therefore, the platform on which surveys were distributed was chosen as the result of the consideration of age and gender distribution.

\subsection{Questionnaire Design}

The questionnaire was designed according to the suggestions of Dillman (2007). It consisted of four parts: attitude toward package marketing, attitude toward advertising, purchase intention, and respondent characteristics. Appendix A lists the final measurement items. Six items selected as measures of attitude toward package marketing were based upon previous studies (Mehta, 2000).

Attitude toward advertising was measured on a sevenitem scale which had been employed in previous marketing literature (Putrevu and Lord, 1994). In the questionnaire, the representative product to be adopted to evaluate attitude toward advertising had to possess practical marketing benefits. Therefore, this study conducted a practical analysis on the advertisements in each Taipei Metro station in June, 2013, and the results showed that health food products, which accounted for approximately $30 \%$ of all the advertisements, were the pervasive advertisement. Therefore, this study selected one health food to be printed on an advertising pamphlet, and the first draft of the pamphlet design, with the coupon design, were sent to experts to ask for their opinions, based on which the advertising pamphlet was revised.

Purchase intention was measured on an eleven-item scale (Gronholdt et al., 2000; Putrevu and Lord, 1994; Zeithaml et al., 1996). Seven-point Likert scale anchors were used for attitude toward package marketing, attitude toward advertising, and purchase intention. Respondents were asked to indicate their levels of agreement with each item, where 1 represented "Strongly Disagree" and 7 represented "Strongly Agree."

\subsection{Choice of Statistical Techniques}

A structural equation modelling (SEM) approach was used to test the research hypotheses. All analyses were carried out using the SPSS 12.0 for Windows and AMOS 19.0 statistical packages.

\section{ANALYSIS}

\subsection{Data Screening and Representativeness}

The data collection phase of the study began in the beginning of August 2013 and ended in the middle of November 2013. To increase the quality and representativeness of the analysed data, this study adopted the following approaches: First, samples with very short responding time were removed (based on the pre-test, the reasonable responding time of this questionnaire can be by no means shorter than two minutes). Second, the gender ratio of the respondents of the collected samples was maintained at 1:1 through random sampling. Consequently, 184 valid samples were obtained, a number that satisfied the sample number requirement of the SEM approach (greater than 100) (Kline, 2011; Schumacker and Lomax, 2010).

\subsection{Descriptive Statistics}

Of the 184 valid respondents, $98 \%$ were between $20-40$ years of age, $75 \%$ had more than three years' online shopping experience, and $81 \%$ had received advertising pamphlets in packages. This suggested that most of the respondents had been the target clients of package marketing.

\subsection{Measurement Model and Structural Model}

Results of the SEM analysis are presented in Table $\mathbf{1}$ and Table 2. Confirmatory factor analysis was conducted to evaluate the reliability and validity of the construct. After deleting the five variables with factor loading smaller than 0.6 or larger MI values (Hair, 2006), the criteria of fit indexes for each construct were marginally satisfied. The composite reliabilities of the different measures ranged from 0.810 to 0.954 , exceeding the recommended threshold value of 0.700 (Fornell and Larcker, 1981). Table 1 also presents average variance extracted (AVE) as well as correlations between constructs. The AVE for every measure fulfilled Fornell and Larcker's (1981) suggested value of 0.5 . These results verify the convergent validity of our measures. The correlation matrix indicated that the square root of AVE of each measure was higher than the corresponding correlation values for that variable in all of the cases, thereby verifying the discriminant validity (Hair et al., 2014). In sum, the results shown in Table 1 provide support for the measures' reliability and validity.

The results of the SEM analysis on the research model and the response to hypotheses are presented in Table 2 . The results indicated that attitude toward package marketing was found to have a significantly positive influence on attitude toward advertising (Standardized Estimate $=0.625$, Critical Ratio > 1.96), and attitude toward advertising was also found to have a positive influence on purchase intention (Standardized Estimate $=0.737$, Critical Ratio $>1.96$ ). However, there was no significantly positive relationship between attitude toward package marketing and purchase intention (Standardized Estimate $=0.022$, Critical Ratio $<1.96$ ). Thus, these results support $\mathrm{H} 1$ and $\mathrm{H} 3$, but reject $\mathrm{H} 2$. It was confirmed that attitude toward advertising plays a mediating role between attitude toward package marketing and purchase intention. The results implied that consumers' attitude toward package marketing will have a positive influence on attitude toward advertising. However, their attitude toward package marketing does not directly influence purchase intention; a positive attitude toward advertising is therefore required to pose a positive effect upon purchase intention. 
Liu \& Chiang: Adding Value to Logistic Delivery through Package Marketing

Operations and Supply Chain Management 9(3) pp. 154 - 160 (C) 2016

Table 1 Inter-construct correlations: consistency and reliability tests

\begin{tabular}{lccccc}
\hline & CR & AVE & Purchase intention & $\begin{array}{c}\text { Attitude toward } \\
\text { advertising }\end{array}$ & $\begin{array}{c}\text { Attitude toward } \\
\text { package marketing }\end{array}$ \\
\hline Purchase intention & 0.954 & 0.721 & $0.849^{*}$ & & \\
Attitude toward & 0.923 & 0.667 & 0.751 & $0.817^{*}$ & \\
advertising & 0.810 & 0.517 & 0.483 & 0.625 & $0.719^{*}$ \\
Attitude toward package marketing & & & & &
\end{tabular}

* Square root of the AVE on the diagonal.

Table 2 SEM results

\begin{tabular}{|c|c|c|c|c|c|c|}
\hline & Relationships & $\begin{array}{l}\text { Standardized } \\
\text { Estimate }\end{array}$ & $\begin{array}{l}\text { Standard } \\
\text { Error }\end{array}$ & $\begin{array}{c}\text { Critical Ratio } \\
\text { (t-value) }\end{array}$ & $p$ & $\begin{array}{l}\text { Supported/ Not- } \\
\text { supported }\end{array}$ \\
\hline $\mathrm{H} 1$ & $\begin{array}{l}\text { Attitude toward package marketing } \rightarrow \\
\text { Attitude toward advertising }\end{array}$ & 0.625 & 0.112 & 5.956 & *** & Supported \\
\hline H3 & $\begin{array}{l}\text { Attitude toward advertising } \rightarrow \\
\text { Purchase intention }\end{array}$ & 0.737 & 0.112 & 7.135 & $* * *$ & Supported \\
\hline
\end{tabular}

*** $\mathrm{p}<0.001$

Fit Indices (Bollen-Stine): $\chi^{2}=175, \mathrm{df}=132, \chi^{2} / \mathrm{df}=1.327, \mathrm{GFI}=0.937, \mathrm{AGFI}=0.807, \mathrm{SRMR}=0.059, \mathrm{RMSEA}=0.042, \mathrm{NFI}=0.937, \mathrm{TFI}=$ $0.981, \mathrm{CFI}=0.984$

\section{DISCUSSION}

\subsection{Attitude Toward Package Marketing and Purchase Intention}

Attitude toward package marketing did not significantly influence purchase intention (H2).Although there have been several literature proving the positive influence special advertising methods have on purchase intension. Such methods may be outdoor billboards (Bhargava and Donthu, 1999; Woodside, 1990), ad placement in TV programs (Russell and Stern, 2006), or mobile advertisement (Drossos et al., 2007). However, as Kotler et al. (2013) indicates, consumers' responses to these special advertising methods depend on whether they are familiar with these methods. This study considers parcel delivery as a marketing medium. This is a recent, new trend in Taiwanese marketing. Therefore, it is difficult for this special advertising method to make direct connection to purchase intention as consumers are unfamiliar with it.

\subsection{Attitude Toward Package Marketing, Attitude Toward Advertising and Purchase Intention}

A positive and significant relationship was found between attitude toward package marketing and consumers' attitude toward advertising (H1). In the future, when companies implement package marketing, they should devise methods to maintain consumers' positive attitude toward this marketing strategy, such as continuing to provide marketing contents that meet the demands of the consumers. After all, it will be more likely for customers to receive company marketing information and improve their attitude toward advertising if consumers could hold a positive attitude toward package marketing by, for instance, paying more attention to the pamphlets contained in the packages.

A positive and significant relationship was also found between attitude toward advertising and purchase intention (H3). This result corresponds to that of previous research (e.g., Mitchell and Olson, 1981) and indicates that companies that need to contain marketing advertisement in packages should consider how to improve consumers' positive attitude toward advertising, such as providing the most effective service for the target client (Kotler et al., 2013).

Although $\mathrm{H} 2$ was rejected, attitude toward package marketing could still influence positive purchase intention through positive attitude toward advertising. A possible explanation is that a positive attitude toward package marketing could only suggest that the consumers are willing to receive information brought by this particular medium, while the key is that whether the advertisement contents could result in a positive attitude and then influence the purchase intention of consumers. This result is similar to that of MacKenzie et al. (1986) and Shimp (2010), both believing consumers' thoughts or opinions toward advertising methods would first become their overall attitudes toward advertisement, which later on influence their purchase intention.

\section{CONCLUSION AND IMPLICATIONS}

Innovative services and value-added services have become the new profit sources in the supply chain. The objective of this study is to evaluate whether package marketing can add value to logistic delivery and to investigate how package marketing influences consumers' purchase intention in order to provide guidance for companies that may need integrated marketing communications in the future. 
Several contributions have been made by this study in terms of both theory and practice. First, this study provides a theoretical framework to link together attitude toward package marketing, attitude toward advertising, and purchase intention for the consumers. Second, this study has verified that the marketing communication tool contained in the package could positively influence consumers' purchase intention through positive attitude toward advertising, as do other communication media.

The findings have practical and academic implications. First, when choosing marketing media, companies should attempt to cooperate with logistic companies. The marketing communication tool (such as pamphlets) contained in the package could achieve the intended marketing purposes, and, furthermore, differentiated marketing could be directed at potential consumers by examining past transaction records. Second, logistic companies could cooperate with other companies that aim to perform package marketing to enhance the added-value of delivery, acquire differentiation advantage in the market (Porter, 1998), and increase profits. Finally, as suggested by the results of this study, consumers' attitude toward package marketing does not directly influence their purchase intention; rather, a positive attitude toward advertising is needed to pose a positive influence upon purchase intention. Thus, to influence purchase intention, companies that would like to perform package marketing should answer the need of specific groups and improve their positive attitude toward advertising. The findings of this study, however, suffer from several limitations. First, this research was limited to markets in Taiwan. Second, the consumer population was drawn from people of 20-40 years of age, despite the fact that consumers of this range have occupied more than $60 \%$ of the online shopping population in Taiwan (Institute for Information Industry (Taiwan), 2013). Finally, only one representative health food was chosen in the questionnaire to assess the attitude toward advertising.

Therefore, several important issues for further research are suggested and are explained in detail. First, future research could introduce moderator variables to investigate the correlations between variables on a deeper level. Second, the marketing communication tool adopted in this study is a kind of promotional strategy. However, since each marketing communication tool will have a different effect on purchase intention (Chen et al., 1998), in the future, the causal effects between attitude toward package marketing and other variables when adopting various marketing communication tools should be examined. Finally, prospective research could try to identify the difference in marketing effects caused by different types (such as prices) of products when adopting package marketing (Gupta and Cooper, 1992).

\section{REFERENCES}

Ajzen, I. and Fishbein, M. (1980). Understanding Attitudes and Predicting Social Behavior, Prentice-Hall, Englewood Cliffs.
Bhargava, M. and Donthu, N. (1999). Sales response to outdoor advertising. Journal of Advertising Research 39(4), pp. 7-18.

Bode, C., Lindemann, E. and Wagner, S. M. (2011). Driving trucks and driving sales? The impact of delivery personnel on customer purchase behavior. Journal of Business Logistics 32(1), pp. 99-114.

Boyd, T. C. and Mason, C. H. (1999). The link between attractiveness of "extrabrand" attributes and the adoption of innovations. Journal of the Academy of Marketing Science 27(3), pp. 306-319.

Chen, S.-F. S., Monroe, K. B. and Yung-Chein, L. (1998). The effects of framing price promotion messages on consumers' perceptions and purchase intentions. Journal of Retailing 74(3), pp. 353-372.

Choi, J., Lee, A. and Ok, C. (2013). The effects of consumers' perceived risk and benefit on attitude and behavioral intention: A study of street food. Journal of Travel \& Tourism Marketing 30(3), pp. 222-237.

Dedeke, A. (2016). Travel web-site design: Information task-fit, service quality and purchase intention. Tourism Management 54 , pp. 541-554.

Dillman, D. A. (2007). Mail and Internet Surveys: The Tailored Design Method: With New Internet, Visual, and Mixed-Mode Guide. 2nd (2007 update) ed., Wiley, Hoboken.

Drossos, D., Giaglis, G. M., Lekakos, G., Kokkinaki, F. and Stavraki, M. G. (2007). Determinants of effective SMS advertising: An experimental study. Journal of Interactive Advertising 7(2), pp. 16-27.

Fornell, C. and Larcker, D. F. (1981). Evaluating structural equation models with unobservable variables and measurement error. Journal of Marketing Research 18(1), pp. 39-50.

Gnanendran, K. and Iacocca, K. (2015). The point of purchase decision in a supply chain with value-added reselling. International Journal of Production Research 53(22), pp. 6689-6700.

Gronholdt, L., Martensen, A. and Kristensen, K. (2000). The relationship between customer satisfaction and loyalty: Cross-industry differences. Total Quality Management 11(46), pp. S509-S514.

Gupta, S. and Cooper, L. G. (1992). The discounting of discounts and promotion thresholds. Journal of Consumer Research 19(3), pp. 401-411.

Hair, J. F. (2006). Multivariate Data Analysis. 6th ed., Pearson Education International, Upper Saddle River.

Hair, J. F., Hult, G. T. M., Ringle, C. and Sarstedt, M. (2014). A Primer on Partial Least Squares Structural Equations Modeling (PLS-SEM), SAGE, Los Angeles.

Ham, C. D. and Lee, H. S. (2015). Internet media personality: Scale development and advertising implications. International Journal of Advertising 34(2), pp. 327-349.

Hsu, M. H., Chang, C. M. and Chuang, L. W. (2015). Understanding the determinants of online repeat purchase intention and moderating role of habit: The case of online group-buying in Taiwan. International Journal of Information Management 35(1), pp. 45-56.

Huh, J., Delorme, D. E. and Reid, L. N. (2015). Do consumers avoid watching over-the-counter drug advertisements? An analysis of cognitive and affective factors that prompt advertising avoidance. Journal of Advertising Research 55(4), pp. 401415.

Institute for Information Industry (Taiwan). (2013). Analysis of the e-shopping experience in Taiwan. Journal of Digital Knowledge 34, pp. 3-7 (in Chinese). 
Jacobs, F. R., Chase, R. B. and Jacobs, F. R. (2011). Operations and Supply Chain Management. 13th ed., McGraw-Hill Irwin, New York.

Keaveney, S. and Parthasarathy, M. (2001). Customer switching behavior in online services: An exploratory study of the role of selected attitudinal, behavioral, and demographic factors. Journal of the Academy of Marketing Science 29(4), pp. 374390.

Kim, S. B., Sun, K. A. and Kim, D. Y. (2013). The influence of consumer value-based factors on attitude-behavioral intention in social commerce: The differences between high- and lowtechnology experience groups. Journal of Travel \& Tourism Marketing 30(1-2), pp. 108-125.

Kline, R. B. (2011). Principles and Practice of Structural Equation Modeling. 3rd ed., Guilford, New York.

Kotler, P., Keller, K. L., Sutherland, D. and Sutherland, J. (2013). Marketing Management. 14th ed., Pearson, Boston.

Lin, Y. C., Wang, C. J. and Wang, J. J. (2016). Effects of a gerotranscendence educational program on gerotranscendence recognition, attitude towards aging and behavioral intention towards the elderly in long-term care facilities: A quasi-experimental study. Nurse Education Today 36, pp. 324-329.

Lin, Y. T. and Chen, Y. J. (2015). Competitive outsourcing: Choosing between value-added services and key component supplying capability. International Journal of Production Research 53(12), pp. 3635-3650.

Lu, B. Z., Fan, W. G. and Zhou, M. (2016). Social presence, trust, and social commerce purchase intention: An empirical research. Computers in Human Behavior 56, pp. 225-237.

Luo, X. and Donthu, N. (2006). Marketing's credibility: A longitudinal investigation of marketing communication productivity and shareholder value. Journal of Marketing 70(4), pp. 70-91.

MacKenzie, S. B., Lutz, R. J. and Belch, G. E. (1986). The role of attitude toward the $\mathrm{Ad}$ as a mediator of advertising effectiveness: A test of competing explanations. Journal of Marketing Research 23(2), pp. 130-143.

Mehta, A. (2000). Advertising attitudes and advertising effectiveness. Journal of Advertising Research 40(3), pp. 6771.

Mitchell, A. A. and Olson, J. C. (1981). Are product attribute beliefs the only mediator of advertising effects on brand attitude? Journal of Marketing Research 18(3), pp. 318-322.

Moorman, M., Neijens, P. C. and Smit, E. G. (2002). The effects of magazine-induced psychological responses and thematic congruence on memory and attitude toward the Ad in a reallife setting. Journal of Advertising 31(4), pp. 27-40.

Oliver, R. L., Rust, R. T. and Varki, S. (1997). Customer delight: Foundations, findings, and managerial insight. Journal of Retailing 73(3), pp. 311-336.

Ots, M. and Nyilasy, G. (2015). Integrated marketing communications (IMC): Why does it fail? An analysis of practitioner mental models exposes barriers of IMC implementation. Journal of Advertising Research 55(2), pp. 132-145.
Porter, M. E. (1998). Competitive Advantage: Creating and Sustaining Superior Performance: With a New Introduction, Free Press, New York.

Putrevu, S. and Lord, K. R. (1994). Comparative and noncomparative advertising: Attitudinal effects under cognitive and affective involvement conditions. Journal of Advertising 23(2), pp. 77-91.

Russell, C. A. and Stern, B. B. (2006). Consumers, characters, and products: A balance model of sitcom product placement effects. Journal of Advertising 35(1), pp. 7-21.

Sabour, N. I., Pillai, D., Gistri, G. and Balasubramanian, S. K. (2016). Attitudes and related perceptions about product placement: a comparison of Finland, Italy and the United States. International Journal of Advertising 35(2), pp. 362387.

Schiffman, L. G., Kanuk, L. L. and Wisenblit, J. (2010). Consumer Behavior. 10th ed., Pearson Prentice Hall, Boston.

Schumacker, R. E. and Lomax, R. G. (2010). A Beginner's Guide To Structural Equation Monitoring. 3rd ed., Routledge, New York.

Seric, M., Gil-Saura, I. and Ozretic-Dosen, D. (2015). Insights on integrated marketing communications: Implementation and impact in hotel companies. International Journal of Contemporary Hospitality Management 27(5), pp. 958-979.

Shamdasani, P. N., Stanaland, A. J. S. and Tan, J. (2001). Location, location, location: Insights for advertising placement on the Web. Journal of Advertising Research 41(4), pp. 7-21.

Shimp, T. A. (1981). Attitude toward the Ad as a mediator of consumer brand choice. Journal of Advertising 10(2), pp. 948.

Shimp, T. A. (2010). Integrated Marketing Communications in Advertising and Promotion. 8th ed., South-Western/Cengage Learning, United States.

Stafford, M. R., Stafford, T. F. and Day, E. (2002). A contingency approach: The effects of spokesperson type and service type on service advertising perceptions. Journal of Advertising 31(2), pp. 17-35.

Van, H. T., Choocharukul, K. and Fujii, S. (2014). The effect of attitudes toward cars and public transportation on behavioral intention in commuting mode choice-A comparison across six Asian countries. Transportation Research Part A-Policy and Practice 69, pp. 36-44.

Von Massow, M. and Canbolat, M. (2014). A strategic decision framework for a value added supply chain. International Journal of Production Research 52(7), pp. 1940-1955.

Woodside, A. G. (1990). Outdoor advertising as experiments. Journal of the Academy of Marketing Science 18(3), pp. 229237.

Zeithaml, V. A. (1988). Consumer perceptions of price, quality, and value: A means-end model and synthesis of evidence. Journal of Marketing 52(3), pp. 2-22.

Zeithaml, V. A., Berry, L. L. and Parasuraman, A. (1996). The behavioral consequences of service quality. Journal of Marketing 60(2), pp. 31-46.

Zhang, Y. and Zinkhan, G. M. (2006). Responses to humorous ADS: Does audience involvement matter? Journal of Advertising 35(4), pp. 113-127. 


\begin{tabular}{|c|c|c|}
\hline Source & Scale & Scale type \\
\hline $\begin{array}{l}\text { Mehta } \\
(2000)\end{array}$ & $\begin{array}{l}\text { A.1 Attitude toward package marketing } \\
\text { 1. I will pay attention to the pamphlets attached when I receive a parcel. } \\
\text { 2. Most of the pamphlets attached in parcels are not bothersome. } \\
\text { 3. The pamphlets attached in parcels help me follow up the products I need or am interested in. } \\
\text { 4. On average, products that are advertised on the pamphlets attached to parcels have better quality. } \\
\text { 5. Most products are as good as advertised on the pamphlets attached to parcels. } \\
\text { 6. Messages on the pamphlets attached to parcels serve more as package components than having actual } \\
\text { effects. (Reverse wording) }\end{array}$ & \multirow[t]{3}{*}{$\begin{array}{l}\text { 7-point } \\
\text { Likert: } \\
\text { Strongly } \\
\text { disagree } \\
\text { (1)/Strongly } \\
\text { agree (7) }\end{array}$} \\
\hline $\begin{array}{l}\text { Putrevu } \\
\text { and Lord } \\
(1994)\end{array}$ & $\begin{array}{l}\text { A.2 Attitude toward advertising (When I see a pamphlet as I open a parcel, I feel that...) } \\
\text { 1. I believe that the contents presented on the pamphlet are true. } \\
\text { 2. I trust the words on the pamphlet. } \\
\text { 3. I believe that this a pamphlet with sincerity. } \\
\text { 4. I believe that it would be a good idea to purchase the products introduced by the pamphlet. } \\
\text { 5. I believe that people would satisfy with the products introduced by the pamphlet. } \\
\text { 6. I believe that the features of products introduced by the pamphlet are helpful to me. } \\
\text { 7. I have a good impression of the products introduced by the pamphlet. }\end{array}$ & \\
\hline $\begin{array}{l}\text { Gronholdt } \\
\text { et al. } \\
\text { (2000); } \\
\text { Putrevu } \\
\text { and Lord } \\
\text { (1994); } \\
\text { Zeithaml } \\
\text { et al. } \\
\text { (1996) }\end{array}$ & $\begin{array}{l}\text { A.3 Purchase intention } \\
\text { 1. If I were to purchase this type of health food, this brand would be my first choice. } \\
\text { 2. It is very likely that I purchase this particular health food of this brand. } \\
\text { 3. If I have needs for this type of health food in the future, I will choose this brand. } \\
\text { 4. I will definitely try this health food of this brand. } \\
\text { 5. I will purchase more health food of this brand. } \\
\text { 6. I will share to the others the benefits of this health food of this brand. } \\
\text { 7. If asked, I will recommend this health food of this brand. } \\
\text { 8. I will recommend this health food of this brand to families and friends. } \\
\text { 9. I will purchase other products of this brand. } \\
\text { 10. I will purchase less health food of this particular type from other brands when I try this brand out. } \\
\text { 11. I am still willing to purchase this health of this brand even when it is more expensive. }\end{array}$ & \\
\hline
\end{tabular}

Dr. Chiung-Lin Liu is an Assistant Professor of Shipping and Transportation Management at National Taiwan Ocean University (NTOU). He holds a Master's in Transportation Technology and Management from National Chiao Tung University, Taiwan, and a $\mathrm{PhD}$ in Management from the University of Liverpool, UK. His current research interests include third party logistics management, logistics outsourcing, and cross-national comparative research. Prior to joining NTOU, he was with the Fuzhou University, PR China where he served as Lecture in the Department of Logistics Management.

Chun-Wei Chiang graduated in Transportation Management from Tamkang University (Taiwan). He has a Masters in Shipping and Transportation Management from National Taiwan Ocean University (Taiwan). He is currently a Section Manager at the Kerry Logistics, Taiwan where he is in charge of the operational areas of the company. 